\title{
Perceived Constraints in Mushroom Production Enterprise in West Bengal
}

\author{
Rakesh Roy*, Bankim Chandra Rudra, Debjyoti Majumder and Adwaita Mondal \\ Malda Krishi Vigyan Kendra, Uttar Banga Krishi Viswavidyalaya, \\ Ratua, Malda-732205, West Bengal, India \\ *Corresponding author
}

\section{A B S T R A C T}

\begin{tabular}{|l|}
\hline Ke y w o r d s \\
Constraints, \\
Economical, \\
Infrastructural, \\
Mushroom, \\
Marketing, \\
Technical \\
\hline Article Info \\
\hline $\begin{array}{l}\text { Accepted: } \\
\text { 12 March } 2020 \\
\text { Available Online: } \\
\text { 10 April } 2020\end{array}$ \\
\hline
\end{tabular}

The study was undertaken with an objective to assess perceived constraints of mushroom grower in mushroom production enterprise. The study was purposively undertaken in flood prone Malda district of West Bengal due to gaining popularity of mushroom production enterprise among rural women and unemployed rural youth who were adopting this venture for employment generation. The rural youth were very much interested in mushroom production enterprise but now they have perceived various constraints in adoption of this enterprise for self-employment. The various perceived constraints were assessed in terms of technical, economical, infrastructural, general and marketing constraints. Unavailability of quality spawn was highest ranked technical constraints. High cost of spawn and poor supply of spawn at appropriate time were highest ranked economical and infrastructural constraints respectively. Poor knowledge about nutritive value of mushroom and lack of local market were highest ranked general and marketing constraints respectively. It is therefore recommended that constraints should be minimized to boost up the enterprises. To do that, policy makers should come up with some suitable policies to minimize these constraints. Further, the extension agencies should take up skill oriented training programmes and awareness programmes for the mushroom growers and rural youth in large scale for their self-employment.

\section{Introduction}

Mushroom is a fungal growth that typically takes the form of a domed cap on a stalk, with gills on the underside of the cap. Mushroom also called 'white vegetables' or 'boneless vegetarian meat' contains ample amounts of proteins, vitamins and fibre (Sharma et al., 2016). India has great potential for production of mushroom from abundantly available recyclable agro-waste like cereals straws, enormous domestic market, cheap manpower, congenial climate, strong technical base and government support. Mushroom growing has been appreciated as a technically feasible and profitable venture and widely accepted by the researchers as a good venture for his income, employment generation and rural development.

Though it is highly recommended by researchers and extension agents but the famers find various constraints in adoption of this enterprise. Researchers have revealed that 
non availability of spawn, lack of wellorganized markets, poor knowledge about financial assistance, news on mushroom poisoning and inadequate knowledge about mushroom preservation and recipes of mushroom items are the major constraints towards a sustainable mushroom industry (Majumder et al., 2009 and Sharma et al., 2016). An attempt was undertaken to find out the perceived constraints of these mushroom growers in the study area.

\section{Materials and Methods}

The study was purposively conducted under flood prone Malda district in West Bengal where Mushroom cultivation is gaining popularity among rural women and unemployed rural youth who were adopting this venture for employment generation. The various perceived constraints were assessed in terms of technical, economical, infrastructural, general and marketing constraints. Respondents were selected from randomly selected 4 blocks of flood prone area of Malda district i.e., Harishchandrapur I, Ratua I, Ratua II and Manikchak through snowball sampling techniques. In all 80 respondents were selected having equal proportion of respondents from each block (i.e., 20 per block).

Constraints in adoption of mushroom production enterprise were measured by Henry Garrett Ranking Method. Garrett ranking technique (Garrett, 1981) was adopted to find constraints in adoption of mushroom production enterprise. The respondents were asked to rank the factors given. The orders of merit, assigned by the respondents were converted into ranks by using the following formula.

Percent Position of Each Rank = $100(\mathrm{Rij}-$ $0.5) / \mathrm{Nj}$
$\mathrm{R}=$ Rank given for $\mathrm{i}^{\text {th }}$ factor by $\mathrm{j}^{\text {th }}$ individual

$\mathrm{N}=$ Number of factors ranked by $\mathrm{j}^{\text {th }}$ individual

The percentage position of each rank thus obtained is converted into scores by referring to the table given by Henry Garrett. Then for each factor the scores of individual respondents were added together and divided by the total number of respondents for whom the scores were added.

\section{Results and Discussion}

Perceived constraints in mushroom production enterprise

The constraints in adoption of mushroom production enterprise were measured by Garret ranking method. Further, the constraints were measures in terms of technical, economical, infrastructural, general and marketing constraints. These fives aspects of constraints were discussed in details below.

\section{Technical constraints}

Table 1 shows that unavailability of quality spawn $(\mathrm{MS}=71.83)$ was highest ranked constraint followed by high incidence of insect-pest and disease (MS = 64.75) and lack of knowledge about composting ( $\mathrm{MS}=54.60)$ were the major perceived constraints in terms of technical constraints in mushroom production enterprise by mushroom grower. Sharma et al., (2016) reported that main problem related to production of mushroom was that of insect-pest attack and incidence of diseases was high.

\section{Economical constraints}

Table 2 depicts that high cost of spawn (MS= 70.95) was highest ranked constraint followed by unawareness about different sources of credit $(\mathrm{MS}=$ 55.10) and high initial 
investment $(\mathrm{MS}=53.46)$ were the major perceived constraints in terms of economical constraints in mushroom production enterprise by mushroom grower. Lack of government scheme for mushroom production was major economic constraints (Kumari et al., 2018). Roy et al., (2018) reported that lack of credit facility was the major financial constraints in adoption of Darjeeling mandarin orange.

Table.1 Perceived technical constraints in mushroom cultivation

\begin{tabular}{|r|l|c|c|c|}
\hline SI. No. & \multicolumn{1}{|c|}{ Constraints } & Score & $\begin{array}{c}\text { Mean Score } \\
\text { (MS) }\end{array}$ & Rank \\
\hline 1. & Unavailability of quality spawn & 5746 & 71.83 & I \\
\hline 2. & High incidence of insect-pest and disease & 5180 & 64.75 & II \\
\hline 3. & Lack of knowledge about composting & 4368 & 54.60 & III \\
\hline $\mathbf{4 .}$ & Complex spawn production technology & 4043 & 50.54 & IV \\
\hline 5. & Irregular production & 3586 & 44.83 & V \\
\hline 6. & Lack of technical guidance in host harvest technology & 3384 & 42.30 & VI \\
\hline 7. & Insufficient literate on mushroom cultivation & 3190 & 39.88 & VII \\
\hline 8. & Lack of trained extension workers & 2903 & 36.29 & VIII \\
\hline
\end{tabular}

Table.2 Perceived economical constraints in mushroom cultivation

\begin{tabular}{|r|l|c|c|c|}
\hline SI. No. & \multicolumn{1}{|c|}{ Constraints } & Score & $\begin{array}{c}\text { Mean Score } \\
(\text { MS) }\end{array}$ & Rank \\
\hline $\mathbf{1 .}$ & High cost of spawn & 5676 & 70.95 & I \\
\hline $\mathbf{2 .}$ & High initial investment & 4277 & 53.46 & III \\
\hline $\mathbf{3 .}$ & Unawareness about different sources of credit & 4408 & 55.10 & II \\
\hline $\mathbf{4 .}$ & Difficult loaning procedure & 3369 & 42.11 & VI \\
\hline $\mathbf{5 .}$ & Lack of government initiative in funding loans & 3772 & 47.15 & IV \\
\hline $\mathbf{6 .}$ & High rate of interest on loans & 3499 & 43.74 & V \\
\hline $\mathbf{7 .}$ & Unavailability of subsidy on loan & 3319 & 41.49 & VII \\
\hline
\end{tabular}

Table.3 Perceived infrastructural constraints in mushroom cultivation

\begin{tabular}{|r|l|c|c|c|}
\hline SI. No. & \multicolumn{1}{|c|}{ Constraints } & Score & $\begin{array}{c}\text { Mean Score } \\
\text { (MS) }\end{array}$ & Rank \\
\hline 1. & Poor supply system of spawn at appropriate time & 5618 & 70.23 & I \\
\hline $\mathbf{2 .}$ & $\begin{array}{l}\text { Poor delivery system of technical inputs at the door } \\
\text { steps }\end{array}$ & 4116 & 51.45 & III \\
\hline 3. & Unavailability of compost in time & 4723 & 59.04 & II \\
\hline $\mathbf{4 .}$ & Lack of cold storage facilities & 3703 & 46.29 & IV \\
\hline $\mathbf{5 .}$ & Unavailability of quality raw material in the area & 3488 & 43.60 & V \\
\hline $\mathbf{6 .}$ & Unavailability of skilled labourers & 3353 & 41.91 & VI \\
\hline 7. & Lack of knowledge about training facilities & 3319 & 41.49 & VII \\
\hline
\end{tabular}


Table.4 Perceived general constraints in mushroom cultivation

\begin{tabular}{|c|l|c|c|c|}
\hline Sl. No. & \multicolumn{1}{|c|}{ Constraints } & Score & $\begin{array}{c}\text { Mean Score } \\
\text { (MS) }\end{array}$ & Rank \\
\hline 1. & Poor knowledge about nutritive value of mushroom & 5491 & 68.64 & I \\
\hline 2. & Social taboos among people & 5061 & 63.26 & II \\
\hline 3. & Misconception about mushroom consumption & 4600 & 57.50 & III \\
\hline 4. & Less risk bearing capacity of mushroom grower & 4019 & 50.24 & IV \\
\hline 5. & Lack of marketing intelligence & 3612 & 45.15 & V \\
\hline 6. & Lack of mushroom growers in the area & 3344 & 41.80 & VI \\
\hline 7. & Lack of transportation facilities & 3250 & 40.63 & VII \\
\hline 8. & People regard mushroom as a non-veg. food & 3023 & 37.79 & VIII \\
\hline
\end{tabular}

Table.5 Perceived marketing constraints in mushroom cultivation

\begin{tabular}{|c|l|c|c|c|}
\hline SI. No. & \multicolumn{1}{|c|}{ Constraints } & Score & $\begin{array}{c}\text { Mean Score } \\
\text { (MS) }\end{array}$ & Rank \\
\hline 1. & Lack of local market & 5459 & 68.24 & I \\
\hline 2. & Less remunerative price for mushroom & 5047 & 63.09 & II \\
\hline 3. & Lack of regular market & 4605 & 57.56 & III \\
\hline 4. & Fluctuation of market price & 4103 & 51.29 & IV \\
\hline 5. & Existence of the middlemen & 3569 & 44.61 & V \\
\hline 6. & Perishable nature of mushrooms & 3328 & 41.60 & VII \\
\hline 7. & Problems in grading and packaging & 3345 & 41.81 & VI \\
\hline 8. & $\begin{array}{l}\text { Lack of organized marketing channels through } \\
\text { cooperatives }\end{array}$ & 2944 & 36.80 & VIII \\
\hline
\end{tabular}

\section{Infrastructural constraints}

Table 3 reveals that poor supply of spawn at appropriate time $(\mathrm{MS}=70.23)$ was highest ranked constraint followed by unavailability of compost in time $(\mathrm{MS}=59.04)$ and poor delivery system of technical inputs at the door steps $(\mathrm{MS}=51.45)$ were the major perceived constraints in terms of infrastructural constraints in mushroom production enterprise by mushroom grower. Lack of cold storage facilities was the major constraints in storage constraints (Singh et al., 2008).

\section{General constraints}

Table 4 shows that poor knowledge about nutritive value of mushroom $(\mathrm{MS}=68.64)$ was highest ranked constraint followed by social taboos among people $(\mathrm{MS}=63.26)$ and misconception about mushroom consumption $(\mathrm{MS}=57.50)$ were the major perceived constraints in terms of general constraints in mushroom production enterprise by mushroom grower.

\section{Marketing constraints}

Table 5 depicts that lack of local market (MS= 68.24) was highest ranked constraint followed by less remunerative price for mushroom $(\mathrm{MS}=63.09)$ and lack of regular market (MS= 57.56) were the major perceived constraints in terms of marketing of mushroom by mushroom grower. Lack of proper marketing channel was major 
constraints in adoption of mushroom production enterprises (Goutam et al., 2014 and Kumari et al., 2018). Fluctuating price prevailing in the market was the major marketing constraints (Singh et al., 2008).

It is already established that mushroom production enterprise has a high potential in employment generation of rural youth. But, the study has shown that the mushroom growers perceived various constraints in adoption of mushroom production enterprises in the study area. It is therefore recommended that constraints should be minimized to boost up this enterprise. To do that, policy makers should come up with some suitable policies to minimize these constraints. Further, the extension agencies should take up skill oriented training programmes and awareness programmes for the mushroom growers and rural youth in large scale for their selfemployment.

\section{References}

Garrett, H.E. (1981). Statistics in Psychology and Education. Published by Vakils, Feffer and Simons Ltd., Mumbai.

Goutam, A.K., Singh, P., Mishra D., Kumar, A. and Singh, A.P. (2014). Constraints in adoption of mushroom production enterprise. Indian Journal of Extension
Education, 50(1\&2):39-41

Kumari, A.R, Singh, D.P., Singh, A., Laxmikant and Kumari, M. (2018). Adoption level and Constraints in Scientific Mushroom Cultivation among Rural Women. International Journal of Current Microbiology and Applied Sciences, 7: 1280-1287

Majumder, D., Das, P.K. and Gogoi, R. (2009). Adoption of recommended mushroom production technology and strategies for developing mushroom industry in Assam. Mushroom Research, 18(2):83-90

Roy, R., Kharga, B.D. and Moktan, M.W. (2018). Darjeeling mandarin orange: reasons for its decline and perceived constraints. International Journal of Current Microbiology and Applied Sciences, 7(9): 14-20

Sharma, D., Kumar, A. and Guleria, J.S. (2016). Economic viability, technological gap and problems of mushroom cultivation in Mandi district of Himachal Pradesh. Himachal Journal of Agricultural Research, 42(1): 47-54

Singh, N., Mehta, S., Godara, A.K. and Yadav, V.P. (2008). Constraints in mushroom production technology in Haryana. Agric. Sci. Digest, 28(2):118120.

\section{How to cite this article:}

Rakesh Roy, Bankim Chandra Rudra, Debjyoti Majumder and Adwaita Mondal. 2020. Perceived Constraints in Mushroom Production Enterprise in West Bengal. Int.J.Curr.Microbiol.App.Sci. 9(04): 1579-1583. doi: https://doi.org/10.20546/ijcmas.2020.904.185 